УДК [378.018.8:37.011.3-051]:[37.017.06:124.5]

DOI https://doi.org/10.26661/2522-4360-2021-2-17

\title{
ЯКІСНА ПРОФЕСІЙНА ПІДГОТОВКА МАЙБУТНІХ УЧИТЕЛІВ У КОНТЕКСТІ АКСІОЛОГІЧНОЇ ПАРАДИГМИ ПЕДАГОГІЧНОЇ ОСВІТИ
}

\author{
Біляковська О. О. \\ доктор педагогічних наук, дочент, \\ професор кафедри загальної педагогіки та педагогіки вищої школи \\ Львівський національний університет імені Івана Франка \\ вул. Університетська, 1, Львів, Україна \\ orcid.org/0000-0003-2880-6826 \\ olha.bilyakovska@Inu.edu.ua
}

Ключові слова: аксіологія, аксіологічна складова частина, професійна підготовка, иінності, ијіннісні орієнтацій, майбутні вчителі.
У статті наголошено на вагомості аксіологічної складової частини у процесі професійної підготовки майбутніх учителів. Зауважено, що відмова від традиційних основ освіти, перехід на компетентнісну й особистісно зорієнтовану освітню парадигму, реалізація гуманістичних принципів, продуктивна взаємодія учасників освітнього процесу на суб'єкт-суб'єктних засадах потребує якісно нової концепції підготовки майбутніх учителів. Аксіологічна складова частина виступає важливим компонентом педагогічної освіти, визначає ціннісний орієнтир майбутнього вчителя, сприяє особистісному розвиткові та формуванню ціннісних орієнтацій, які забезпечать ефективну професійну діяльність. Процес навчання на кожному етапі професійної підготовки не може якісно відбуватися без свідомо визначених цінностей, які регулюють та впорядковують усю систему. Саме цінності визначають змістову основу професійної підготовки майбутніх учителів, а освітній процес у закладах вищої освіти - це не лише трансформація системи знань, а й озброєння студентів системою загальнолюдських і професійних цінностей, які становлять зміст особистих переконань та педагогічного бачення. Окреслено основні напрями розвитку ціннісних орієнтацій у процесі професійної підготовки майбутніх учителів. Зазначено, що формування ціннісних орієнтацій майбутніх учителів - досить складний та тривалий процес, який виключає нав'язування, потребує делікатності у становленні аксіологічної позиції. Наголошено, що основу аксіологічних орієнтирів майбутнього вчителя повинні становити національні цінності, які об'єднують загальнолюдське та ментальне, формують аксіосферу педагога, стимулюють духовний розвиток особистості. Розглянуто етапи формування ціннісних орієнтацій майбутніх учителів та виокремлено умови, які сприяють вирішенню аксіологічних проблем у процесі професійної підготовки. Якісна професійна підготовка повинна спиратися на цінності, які стануть життєвим ресурсом майбутніх учителів, що формує сенс життя, визначає цілі, постає своєрідним орієнтиром у провадженні педагогічної діяльності. 


\title{
QUALITATIVE TEACHER TRAINING IN THE CONTEXT OF THE AXIOLOGICAL PARADIGM OF PEDAGOGICAL EDUCATION
}

\author{
Bilyakovska O. O. \\ Doctor of Pedagogical Sciences, Associate Professor, \\ Professor at the Department of General Pedagogy and Pedagogy of Higher School \\ Ivan Franko National University of Lviv \\ Universytetska str., 1, Lviv, Ukraine \\ orcid.org/0000-0003-2880-6826 \\ olha.bilyakovska@lnu.edu.ua
}

Key words: axiology, axiological component, professional training, values, value orientations, future teachers.
The article emphasizes the significance of the axiological component in the process of teacher training. It is noted that the rejection of traditional basics of education, transition to a competence and personality-oriented educational paradigm, implementation of humanistic principles, productive cooperation of participants of the educational process on the person to person principles require qualitatively new concept of teacher training. The axiological component is an important part of pedagogical education; it defines value orientation of a future teacher and contributes to personal development and formation of value orientations ensuring effective professional activity. The teaching/learning process cannot be qualitative at each stage of teacher training without consciously defined values that regulate and manage the whole system. These are the values that determine the basics of the content of teacher training, while the educational process in higher education institutions means not only transforming the system of knowledge but also equipping students with the system of universal and professional values, which constitute the content of personal beliefs and pedagogical vision. The main directions of development of value orientations in the process of teacher training are outlined. The formation of value orientations of future teachers is noted to be quite a complex and lasting process that excludes intrusion and requires delicacy while building the axiological point. National values uniting universal and mental points, building the pedagogue's axiosphere and stimulating spiritual development of an individual are emphasized to create the grounds for axiological orientations of a future teacher. Stages of creating value orientations of future teachers are considered and conditions that contribute to solving axiological problems in the process of teacher training are outlined. Qualitative professional training should be based on values that will become a life resource for future teachers that forms the sense of life, defines goals, and becomes a kind of a guide while carrying out pedagogical activity.
Постановка проблеми. Сучасні зміни у системі вітчизняної освіти зумовлені перетвореннями у політичній, економічній, правовій, культурній сферах суспільства. Процеси інтеграції української освіти у світовий освітній простір детермінують модернізаційні перетворення на всіх ланках освітньої системи. Основним пріоритетом освітньої політики постає якість вищої освіти, що спрямовує заклади вищої освіти на вдосконалення освітнього процесу, забезпечення якісної підготовки майбутніх фахівців, творення культури якості. Освіта сьогодні виступає індикатором цінностей кожного суспільства, а якісна освіта - віддзеркаленням системи цінностей кожної особистості зокрема. Водночас сучасна система освіти поєднує у собі три різні ціннісні виміри - культури, політики та ринку [2, с. 62], які певним чином впливають на підготовку майбутніх фахівців.

Зазначимо, що інтерес до аксіологічної тематики зумовлений сучасною соціокультурною реальністю, яка характеризується:

- девальвацією традиційних суспільних цінностей, дезорієнтацією щодо ціннісних настанов, які визначені новими суспільними трансформаціями;

- частковим віддаленням системи освіти від запитів суспільства та потреб особистості, недостатністю освітніх форм щодо поширення сучасного знання в органічному поєднанні із загальнолюдськими цінностями;

- нинішні суспільні перетворення породжують нову ціннісну свідомість та поведінку, що 
зумовлює в освіті необхідність аксіологічного підходу для формування людини цифрової епохи.

Власне відмова від традиційних основ освіти, перехід на компетентнісну й особистісно зорієнтовану освітню парадигму, реалізація гуманістичних принципів, взаємодія учасників освітнього процесу на суб'єкт-суб'єктних засадах потребує якісно нової концепції підготовки майбутніх учителів, стрижнем якої буде аксіологічна компонента.

Засадничі аксіологічні положення в освіті висвітлено у працях В. Андрущенка, I. Беха, С. Вітвицької, С. Гончаренка, М. Євтуха, І. Зязюна, В. Кременя, В. Огнев'юка; проблеми педагогічної аксіології розглядали І. Андріаді, Е. Гусинський, К. Денек, Я. Косткєвич, К. Ольбрихт; ціннісний компонент професійної підготовки майбутніх учителів відображено у наукових доробках А. Акусок, О. Вишневського, В. Гриньової, О. Киричука, Т. Калюжної, О. Сухомлинської, Л. Хомич та інших. Вважаємо за доцільне в межах цієї статті акцентувати на значущості аксіологічного складника для якісної професійної підготовки майбутніх учителів. Аксіологічний складник виступає важливим компонентом педагогічної освіти, визначає ціннісний орієнтир майбутнього вчителя - прагнення дізнатися про свого вихованця, яким він $€$ насправді, з усіма слабкостями й у всій величі, зі всіма його буденними, дріб'язковими потребами і зі всіма великими духовними вимогами [6, с. 367].

Мета статті полягає у розкритті вагомого значення аксіологічного складника у якісній підготовці майбутніх учителів, яка спрямована на формування ціннісних орієнтацій студентів, системи цінностей, що визначатиме їхнє ставлення до професійно-педагогічної діяльності.

Виклад основного матеріалу. Сучасна професійна підготовка майбутніх учителів спрямована на підготовку компетентного вчителя, що поєднує глибокі теоретичні знання із практичною підготовкою, вільно орієнтується у соціальних та освітніх процесах, розуміс особливості розвитку культури. Важливою складовою частиною у змісті педагогічної підготовки $є$ аксіологічна, що сприяє особистісному розвиткові майбутніх учителів, формуванню ціннісних орієнтацій, якісній професійній діяльності. Проте варто зауважити, що у процесі підготовки вчителів значна увага приділена фаховій (предметній) підготовці, методичній, практичній, i, на переконання К. Денека, «із тріади освітніх цілей «знання - підготовка - цінності» останнім приділяють найменше уваги» [8, с. 31]. Як слушно зазначає О. Мартинюк, за «безособової» технологічної організації освітнього процесу більшість студентів оріснтуються не на педагогічну професію, а на предметну спеціалізацію. I, як наслідок, суспільство отримує вчителя-предметника, котрий «більшменш успішно працює у межах класно-урочної системи, але недостатньо володіє навчальним предметом як засобом формування особистості учня та не вміє впливати на процес духовного становлення дитини» [3, с. 29]. Навчання в університеті покликане виховувати особистість, а не лише озброювати іiі системою наукових, професійних знань [11, с. 124]. Адже набагато складнішим $є$ «шлях набуття мудрості, яка становить не просто знання, а знання особливе, знання доброчинності, знання про благо або осягнення вищих ціннісних смислів буття» [1, с. 65].

3 огляду на це можемо стверджувати, що саме цінності визначають змістову основу професійної підготовки майбутніх учителів, а освітній процес у закладах вищої освіти - це не лише трансформація системи знань, а й озброєння студентів системою загальнолюдських і професійних цінностей, які становлять зміст особистих переконань, педагогічного бачення, визначають форму дидактичних і виховних ситуацій $[9$, с. 351$]$.

На переконання науковців [7, с. 225], розвиток ціннісних орієнтацій під час професійної підготовки вчителів повинен здійснюватися у трьох основних напрямах: 1) формування загального ціннісного ставлення студентів до педагогічної професії; 2) формування професійного образу «Я-педагога» у студента; 3) розвиток і формування ціннісних орієнтирів майбутньої професійно-педагогічної діяльності. Відповідно, у процесі професійної підготовки у майбутніх учителів «повинна скластися система професійно-ціннісних орієнтацій, які визначатимуть ставлення до особливостей професії, відображатимуть зміст, основу професійної діяльності, іiі цілі, а засоби регулюватимуть поведінку особистості у професійній діяльності» [7, с. 225].

Формування ціннісних орієнтацій майбутніх учителів - досить складний та тривалий (за часом) процес, який виключає нав'язування, потребує делікатності у становленні аксіологічної позиції. Ціннісні орієнтації - це «стійкі, системно зв'язані ціннісні утворення, в основі яких лежать фіксовані установки, мотивуюча діяльність і поведінка особи відповідно до певних інтересів, потреб і цінностей» $[4$, с. 55]. У ціннісних орієнтаціях цінність виступає певним орієнтиром та своєрідним регулятором поведінки і діяльності. Зокрема, у професійній ціннісній орієнтації вчителя такою цінністю стає професія, коли педагогічні цінності виступають відносно стійкими орієнтирами.

В основі системи аксіологічних орієнтирів у процесі професійної підготовки майбутніх учителів повинні бути національні цінності, що об’єднують загальнолюдське та ментальне, формують аксіосферу педагога, стимулюють духовний розвиток особистості. Важливими європейськими цінностями є: права та свободи людини, мир i неприйняття насилля, демократична правомірність, повага, прийняття іншого, солідарність, гармонійний розвиток, рівність шансів, особистісна відповідальність, охорона довкілля, безпека екосистеми [10, с. 405]. 
Повний цикл формування ціннісних орієнтацій майбутніх учителів може включати такі етапи, як [2, с. 68-69]:

- пред'явлення цінностей;

- усвідомлення ціннісних орієнтацій особистістю;

- ухвалення ціннісної орієнтації;

- реалізація ціннісних орієнтацій у діяльності та поведінці;

- закріплення ціннісної орієнтації у спрямованості особистості і перехід іiі у статус якості особистості;

- актуалізація потенційної ціннісної орієнтації, що відображається в якостях особистості вчителя.

Розглянемо кожен з етапів формування ціннісних орієнтацій, що уможливить виділення головних траєкторій над ціннісним ядром особистості майбутнього вчителя. Отже, пред’явлення цінностей може здійснюватися як у спеціально створених умовах навчальної взаємодії (на лекційних, семінарських заняттях), так і в щоденному спілкуванні. Зазвичай сновний шлях пред'явлення цінностей - це щоденна освітня діяльність в умовах аудиторних занять, суб'єкт-суб'єктна взаємодія «викладач - студент». Викладач постає головною особистістю, яка створює аксіологічні ситуації, пред'являє студентам цінності освіти, суспільства. Важливо, аби внутрішній світ викладача, його компетентність, майстерність, професійна культура були пройняті ціннісним духом і виступали зразком у педагогічній діяльності.

Спеціально створювані на аудиторних заняттях ситуації (дидактична гра, дискусія, діалог-рефлексія, комунікативний тренінг) будуються на основі свободи висловлювань, вибору, широкого обговорення пропонованих варіантів розв'язання проблеми, відсутності будь-якого тиску й авторитарності.

Після пред'явлення цінностей розпочинається етап їх усвідомлення, який вирізняться своєю поступовістю. Цілковите усвідомлення цінностей студентами поєднує усвідомлення змісту ціннісних орієнтацій, здійснення на їх основі дій та ймовірні результати. Таким чином, формується певний стимул, який викликає необхідні прояви особистості, сприяє розвитку професійно значущих якостей, що є важливими для педагогічної діяльності. На цьому етапі ціннісні орієнтації набувають властивості усвідомленості.

Внутрішнє прийняття ціннісної орієнтації студентами перетворює їх на потужну спонукальну силу. Етап ухвалення усвідомленої ціннісної орієнтації проходить в умовах іiі ідентифікації із ціннісно-смисловими утвореннями особистості, у процесі співвідношення ціннісної орієнтації 3 ієрархією суб'єктивно значущих особистісних цінностей. На цьому етапі важливо, аби відбувся процес включення ціннісної орієнтації у структуру відносин, які $є$ важливими та значущими для особистості. За цих умов ціннісна орієнтація набуває смислоутворюючої функції та стає вагомою підставою для організації діяльності, зокрема й професійної.

Важливим 3 огляду поглиблення аксіологічних засад $є$ етап реалізації ціннісних орієнтацій. На цьому етапі проходить демонстрування потенціалу ціннісних орієнтацій, розкривається весь спектр можливостей змісту педагогічної підготовки. До цього етапу ціннісні орієнтації мали властивості усвідомленості, а також проявлялися як певна дієвість. На етапі реалізації ціннісні орієнтації відображатимуть такі функціональні особливості, як стійкість (гуманістичний потенціал, основи духовності), задоволення особистісних (професійних) інтересів.

Особлива увага повинна приділятися етапу закріплення ціннісних орієнтацій. Це безпосередньо пов'язано 3 тим, що для того, аби ціннісна орієнтація стала властивістю особистості майбутнього вчителя, проявлялася в якостях, необхідним $\epsilon$ багаторазове звернення до неї. Студенти повинні переосмислити не лише суть, а й сенс ціннісної орієнтації, щоби постійно, варіативно реалізувати у професійній діяльності. Цей етап вирізняється тим, що ціннісні орієнтації, пройшовши через якісно новий процес розкриття потенційних можливостей, набувають спонукальної властивості.

Завершальний етап - віртуалізації потенційної ціннісної орієнтації - виступає показником сформованості ціннісної орієнтації майбутнього вчителя, оскільки проявляється на рівні якостей особистості як усвідомлено, так і неусвідомлено. Актуалізація ціннісної орієнтації може здійснюватися за допомогою вольових зусиль, досить легко, можливо, і спонтанно. Цей етап фактично завершує цикл формування ціннісної орієнтації й одночасно може слугувати початком нового циклу формування аксіологічних основ особистості.

Так, Т. Калюжна [2, с. 71] зауважує, що «процес формування ціннісних орієнтацій, як і будьяке психолого-педагогічне явище, не може здійснюватися ідеально». Огляду на це, дослідницею виокремлено умови, які сприяють вирішенню аксіологічних проблем у процесі професійної підготовки [2, с. 71-72]:

- вільний розвиток позитивно значущої ціннісної орієнтації;

- глибоке осмислення усвідомлюваної ціннісної орієнтації;

- широке співвідношення ціннісної орієнтації із системою цінностей;

- перенесення значущих ціннісних орієнтацій на різні життєві та професійні ситуаціі;

- самостійний пошук нових професійно й особистісно привабливих цінностей:

- пошук механізмів переходу особистості зі стану «Я реальне» в «Я ідеальне».

Висновки. Проблема цінностей, ціннісних орієнтацій є однією з найбільш актуальних і значущих для сучасної системи освіти та постає предметом осмислення на усіх етапах цивіліза- 
ційного розвитку. Власне аксіологічний рівень розвитку особистості визначається рангом цінностей, трансформованих у ціннісні орієнтації (установки, переконання, інтереси, прагнення, бажання, наміри), стійкістю останніх, багатоплановістю, гармонійністю поєднання. Саме ціннісні орієнтації детермінують ставлення особи до навколишнього світу та самої себе [5, с. 58]. Модернізаційні освітні процеси спрямовані на забезпечення якості вищої освіти. Аксіологічний складник постає невід'ємною частиною якісної підготовки майбутніх учителів, яка спрямована на культурний розвиток та саморозвиток особисто- сті педагога. Процес навчання на кожному етапі професійної підготовки не може якісно відбуватися без свідомо визначених цінностей, які регулюють та впорядковують усю систему.

Таким чином, сучасна підготовка майбутніх учителів повинна спиратися на цінності, які стануть життєвим ресурсом, що формує сенс життя, визначає цілі, є своєрідним орієнтиром у провадженні професійної діяльності. Подальшого дослідження потребує проблема гармонізації прийнятих особистістю цінностей та соціально-необхідних на сучасному етапі цінностей, а також розроблення ціннісних студентоцентричних педагогічних технологій.

\section{ЛIТЕРАТУРА}

1. Вітвицька С.С. Аксіологічний підхід до виховання особистості майбутнього вчителя. Креативна педагогіка : наук.-метод. журнал. 2015. Вип. 10. С. 63-67.

2. Калюжна Т.Г. Педагогічна аксіологія в умовах модернізації професійно-педагогічної освіти: монографія. Київ : Вид-во НПУ імені М.П. Драгоманова, 2012. 128 с.

3. Мартинюк О. Розвиток професійних ціннісних орієнтацій майбутніх учителів. Психологія і суспільство. 2008. № 3. С. 28-40.

4. Підлісний М.М. Проблеми аксіології та шляхи їх вирішення: монографія. Дніпро : Видавець Біла К. О., 2020. 164 с.

5. Рогова О. Аксіологічний аспект гуманітарної парадигми освіти. Грані. 2010. № 4 (72). С. 56-59.

6. Ушинский К.Д. Собрание сочинений. Т. 2. Москва : Изд-во АПН РСФСР, 1948. 655 с.

7. Шарапа С. Аксіологічні аспекти підготовки вчителя у вищих педагогічних навчальних закладах України (кінець XX - початок XXI ст.). Людинознавчі студії. Педагогіка. 2014. Вип. 29 (1). С. 222-228.

8. Denek, K. (2008). Związek edukacji z wartościami. Neodidagmata. № 29/30. S. 25-38.

9. Dróżka, W. (1997). Wartości edukacyjne osoby nauczyciela a kształcenie aksjologiczne. Pedagogika ogylna. Problemy aksjologiczne / red T. Kukołowicz. Lublin. S. 351-352.

10. Pedagogika. Podstawy nauk o wychowaniu. T. 1./ red. B. Śliwerski. Gdańsk : Gdańskie Wydawnictwo Oświatowe, 2006. $446 \mathrm{~s}$.

11. Żuk, G. (2016). Edukacja aksjologiczna. Zarys problematyki. Lublin : Wyd. UMCS. 322 c.

\section{REFERENCES}

1. Vitvytska, S.S. (2015). Aksiolohichnyi pidkhid do vykhovannia osobystosti maibutnoho vchytelia [Axiological approach to the education of future teacher's personality]. Creative pedagogy : scientific methodical journal. Vol. 10. P. 63-67.

2. Kaliuzhna, T.H. (2012). Pedahohichna aksiolohiia v umovakh modernizatsii profesiino-pedahohichnoi osvity [Pedagogical axiology in the conditions of modernization of professional and pedagogical education]: monohrafiia [monograph]. Kyiv.

3. Martyniuk, O. (2008). Rozvytok profesiinykh tsinnisnykh oriientatsii maibutnikh uchyteliv [Development of professional value orientations of future teachers]. Psychology and society. Vol 3. P. 28-40.

4. Pidlisnyi, M.M. (2020). Problemy aksiolohii ta shliakhy yikh vyrishennia: [Problems of axiology and ways of their decision]: monohrafiia [monograph]. Dnipro.

5. Rogova, O. (2010). Rohova O. Aksiolohichnyi aspekt humanitarnoi paradyhmy osvity [Axiological aspect of the humanitarian paradigm of education]. Hrani. Vol. 4 (72). P. 56-59.

6. Ushynskyi, K. D. (1948). Sobranye sochynenyi [Collection of works]. T. 2. Moscow.

7. Sharapa, S. (2014). Aksiolohichni aspekty pidhotovky vchytelia u vyshchykh pedahohichnykh navchalnykh zakladakh Ukrainy (kinets XX - pochatok XXI st.) [Axiological aspects of teacher training at higher educational establishments of Ukraine (the end of XX - the beginning of XXI century)]. Human Studies. Pedagogy. Vol. 29 (1). P. 222-228.

8. Denek, K. (2008). Związek edukacji z wartościami. Neodidagmata. Vol. 29/30. S. 25-38.

9. Dróżka, W. (1997). Wartości edukacyjne osoby nauczyciela a kształcenie aksjologiczne. Pedagogika ogylna. Problemy aksjologiczne / red T. Kukołowicz. Lublin. S. 351-352.

10. Pedagogika. Podstawy nauk o wychowaniu. T. 1. / red. B. Śliwerski. Gdańsk : Gdańskie Wydawnictwo Oświatowe, 2006. $446 \mathrm{~s}$.

11. Żuk, G. (2016). Edukacja aksjologiczna. Zarys problematyki. Lublin : Wyd. UMCS. 322 c. 